\title{
Words as Indices of Social and Cultural Identity
}

\author{
Tatiana A. Ivushkina
}

\begin{abstract}
The paper focuses on words, which alongside with their denotations reflect meanings of social, cultural and historical levels and serve as signs of identity. These words used in literature to depict the upper classes of Great Britain can be grouped into five clusters. The first includes proper names of upper class educational institutions or districts known for their most expensive properties, also words that denote the highest ranks of society, and proper names of the Royal family members and their circle. The second class of words is made up of words - allusions, which are the names of authors, books and reference books depicting the lifestyle and history of the upper classes and underlying their social and cultural codes. Another group of words reflect social signs of the upper class standing by non-verbal, visual means appearance and clothing or fabrics of which clothing is made. In a separate cluster are social events and all attributes accompanying them. Cluster five words characterize voice and manner of speaking which unequivocally reveal social identity.
\end{abstract}

Index Terms-Words, meaning, social and cultural code, identity, the upper classes, literature.

\section{INTRODUCTION}

In recent years the question of social identity has attracted attention of scholars in different fields - sociology, sociolinguistics, linguistic anthropology, discourse theory, etc. (Labov 1966, Tajfel 1978, Edwards 1985, Turner 1987, Wodak 1989, Bourdieu 1991, Silverstein 2003, Agha 2005, Blommaert 2007, Coupland 2007 etc.) who tackling it from different perspectives have considerably enlarged on the details of how language, culture and society interact. Different approaches to the study of social identity find their reflection in the work by Mary Bucholtz and Kira Hall [1] in which they are combined in a "comprehensive toolkit”, as it were, in a framework for the analysis of identity. This framework is based on five fundamental principles that include Emergence, Positionality, Indexicality, Relationality and Partialness. According to Emergence principle, identity is considered an emerging in interaction social and cultural phenomenon. The principle of Positionality presupposes not only macrolevel demographic categories (gender, age, and social status) but also microlevel local identity categories and temporary and interactionally specific stances and roles. The third principle of Indexicality emerges in interaction through "related indexical processes, including: (a) overt mention of identity categories and labels; (b) implicatures and presumptions

Manuscript received May 9, 2017; revised September 5, 2017.

Tatiana Ivushkina is with the Department №3 at MGIMO (University), Moscow, Russia (e-mail: Tatiana.ivushkina@gmail.com). regarding one's own or others' identity position; (c) displayed evaluative and epistemic orientations to ongoing talk, as well as interactional footings and particular roles; and (d) the use of linguistic structures and systems that are ideologically associated with specific personas and groups (p. 21) [1].

The idea of indexicality is in the focus of Peirce's and Silverstein's works. According to Peirce and his semiotic theory, the main property of words, and other signs, is indexicality, their ability to point at levels other than that of their order (p. 17) [2]-[3]. Silverstein claims that such indices pursue an ordered path of development. They start at level one and develop into level two, level three and so on and it is in the interplay between these levels that identity is dialectically constructed (p. 17) [2], [4]. There are always links between linguistic forms and social meanings.

Relationality suggests a much broader range of relations that are forged through identity processes (p. 23) [1]. Because identity is relational, it is also partial, according to the researchers, as "it is produced through contextually situated and ideologically informed configurations of self and other" (p. 25) [1].

Of particular significance for our research is the principle of indexicality expressed in the above-mentioned works on which the analysis of the literary material will be based, as it enables to correlate words with different aspects of people's life and consider them as multifaceted linguistic units communicating identity of the speakers. The verbal and non-verbal means of identifying oneself arose, according to Luis Dessalles, with the necessity 'to show off the values' of 'the social sizeable coalition of their ancestors' [5].

The paper is aimed at singling out language-mediated attributes of social identity and examining how words translate different levels of information, and social meaning in particular.

\section{ABOUT THE RESEARCH}

In the focus of the article are the words used by or about the upper classes of British society in literature, in the book People Like Us, A Season Among The Upper Classes by Charles Jennings [6]. Drawing on this book provides a deep insight into social context of a verbal and non-verbal behavior of the upper classes of society, which differentiates them from the rest. The book is centered around the main character, a graduate from Oxford, who, in order to get into the upper class society and to become one of "them", spends several weeks in their company, living highlife and trying to assimilate their social and cultural codes; but he fails in his attempts and has to acknowledge 
that it's not only education that matters but a host of other factors to be an integral part of upbringing that constructs and frames socio-cultural code of the upper classes. If not inculcated in childhood, they immediately reveal "others". His experience brought him to the realization that "an adult can never attain complete success” (p. 47) [6]. In the focus of the paper are the words conveying verbal and non-verbal information of a socio-cultural character.

\section{WORDS AND THEIR MEANINGS}

Analyzing words of the upper-class speech portrayals and words about them used in the narration, we could single out different categories, or classes, of words. It should be pointed out that the words under analysis lie "on the surface”, as it were, and they either explicitly denote social ranking of the speaker, or character, or assign identity implicitly, by drawing on a lot of proper names, descriptions of appearance and small talks, social events, hobbies and interests, which attract the reader's attention.

\section{A. Class 1}

Class 1 includes, first of all, words denoting the upper class titles and ranks (pp. 239-252) [7], which immediately and explicitly link the words with socially privileged classes of Great Britain and their representatives by their semantic structures- knightly class (p. 109) [6]; titled landowners (p. 147) [6]; baronets (...baronets, of course, being parvenus invented by James 1 , are more like sleazy older brothers or Alan Rickman (p. 153) [6]); quintessentially upper crust (p. 96) [6]; upper crust men and women' (p. 7) [6]; the uppermost people (p. 10) [6]; grandee (p. 81), (p. 152), (p. 160) [6], peers (p. 10) [6], don (a university teacher, a senior member of a college at Oxford or Cambridge), high society of this kind (p. 6) [6]; an earl, privileged classes, gentlefolk (p. 61) [6]; the upper boys (p. 63) [6]; aristos and toffs (p. 59), (p.11), (p. 64) [6]; layabout aristos (p. 96) [6]; debs (p. 111), (p. 118) [6]; paragons (p. 161) [6]; upperclass wastrels (p. 119) [6]. It should be noted that the words with negative, derogatory connotations of the adduced nouns (aristos, toffs, wastrels, etc.) and informal words (upper crust, debs, etc.) reflect the ironic and often envious attitude, as the narrator of the book demonstrates, which index an out-group speaker.

Here also belong the names of the upper-class representatives often used with their titles: the Queen (p. 146) [6], the Queen Mother (p. 26) [6], Prince Phillip, Princess Diana, Margaret, Duchess of Argyll (p. 144) [6], Duke of Edinburgh (p. 26) [6], the Royal family, Randolph Churchill, etc., who are at the top of the social hierarchy in Great Britain and famous world-wide and, therefore, unequivocally suggest social identity.

Class 1 also includes proper names associated with the privileged class institutions, for example, the Old Etonian (p. 3) [6], hardcore smart Oxford clique p. 3 [6]; Harrovians (p.74) [6]; Harrow (“...was like a nursery version of White's Club (p. 5) [6]); dances at houses in Mayfair and Belgravia, great public schools (p. 66) [6], etc.

The names of the most privileged private schools and Universities immediately render, alongside with their locations, social meaning attached to them in the time of their foundation as they were conceived of as the institutions intended to enhance the power and ideology of the aristocracy [8]. They also evoke a historical background of the first universities (the University College, the first of the 39 constituting the Oxford University, was founded in 1249) and public schools (Harrow school, founded under Queen Elizabeth in 1571; Eton, a boys' public school, founded in 1440 by Henry VI to prepare scholars for King's College, Cambridge; Benenden, an independent boarding school for girls in Kent, Westminster school, Marlborough College, Sherborne School for Girls (p. 5) [6]).

The proper names (Eton, Oxford, Harrow and others) are a stable, familiar and re-usable way of indexing class. They are linguistic signs coming to signal upper class culture and "register", which according to Agha, 'are cultural models of action that link diverse behavioral signs to enactable effects, including images of persona, interpersonal relationship, and type of conduct (p. 145) [9]. Even if little or nothing is known about the history and founders of the Universities or schools, the words get linked to upper-class people, to those with money and status.

There are metapragmatic, or contextualized, links between the proper names and contexts, according to Silverstein and Agha [10], [9], which mean the words are linked with social identities explicitly. Being imbued with a host of social, historical, ideological connotations, they can both evoke and construct identities, and they unambiguously index elitism and social superiority.

This class of words corresponds to group (a) "overt mention of identity categories and labels” in Mary Bucholtz and Kira Hall's framework. These words get linked with their social meanings by virtue of co-occurring with the titles and ranks of the British society they are taken to mean; they acquired the status of social indices long ago and the reader easily establishes the links between linguistic forms and social meanings of their referents. The names of the Universities and schools, though belong here and have a direct reference to class, are of a more complex nature as they contain deeper layers of historical and socio-cultural information to infer.

According to Silverstein's n-th+1 indexical order, not only does Eton (or Harrow) denote the name of the boys' public school and its location but it also suggests a closed and exclusive school with high tuition fees. Exclusiveness leads to another level - that of socially privileged classes of society whose interests and ideology are nurtured there. These proper names index social identity of the elite and the aristocracy.

\section{B. Class 2}

Class 2 represents names of the authors and the books about the aristocracy, like Alan Ross, Nancy Mitford and Evelyn Waugh's The Noblesse Oblige (p. 47), (p. 147), (p. 158), (p. 163) [6], in which the notion of $U-$ Non-U words first appeared; The Sloane Ranger's Handbook, a guideline for upbringing an upper class man ("Many of the posh visual trademarks - as listed in the Sloane Ranger's Handbook, among others ...” (p. 4) [6]), the book by Bernard Shaw The Pygmalion (Henry Higgins's Pygmalion (p. 47) [6]) and Brideshead Revisited by Evelyn Waugh (p. 
140) [6], The Upper Class by Peter Lane (p. 14) [6], the "Harper's and Queen" Book of the Season: An Insider Guide by Lady Celestria Noel (p. 20) [6] as well as reference books about the genealogical tree of the British aristocracy Debrett's Peerage and Baronetage compiled by Debrett first in 1803 under the title The Peerage of England, Scotland, and Ireland - “another Debrett's woman” (p. 43) [6]. In the list is John Pearson's The Ultimate Family, The Making of the Royal House Of Windsor, published in 2011.

Among obvious allusions are the names of the magazines popular among the upper-class people, like The Racing Post, The Country Life, The Shooting Times (p. 163) [6], Vogue"...to spot a new boy who'd been photographed in the society pages of Vogue" (p. 4) [6], which reflect the pastimes of the upper class society and, therefore, attribute the corresponding social status to their readers. The magazines explicitly correlate with favourite pastimes and identity. It is well known that riding a horse, shooting, playing golf, and yachting are activities associated with identity, they are part of the register and along with other linguistic forms serve indices of upper-class culture.

The names of the authors and their works explicitly establish connection with identity, they are allusions "lying on the surface", as it were, they index identity of the authors of the books and their in-group. It should be noted, though, that allusions are an indirect, implicit way of conveying information of different orders that presupposes deep knowledge and sensitivity on the part of a reader or listener to grasp it, the ability to infer the meanings conveyed by allusions also testifies to identity. Interestingly, in Charles Jennings's book we more often find obvious allusions references to the social culture of the upper classes. Apparent versus subtle ways of translating identity may also serve as an index of identity.

According to Mary Bucholtz and Kira Hall's framework (Indexicality principle), allusions fall under the category (b) implicatures and presumptions regarding one's own or others' identity position. In order to recognize one of ingroup or a member of out-group, the reader often needs to share the same cultural code and have the same background knowledge.

In Charles Jennings' book we find numerous allusions to different sources, Ashford's book The Young Visitors (1919), in particular, in which the forty-two-year-old Alfred Salteena wishes to become a gentleman, and having taken the lessons from a well-connected earl of Clincham on the secrets of wearing clothes rightly as well as hunting, shooting and riding, Salteena undergoes transformation into Lord and gets a job with a Royal family. We find this reference to the book at the very outset of the narrator's adventure, which translates hope and belief the narrator cherished to get into 'the closed world' and become one of "them". In order to grasp the implied meaning and be able to link the main character and associations he evokes to the narrator of Charles Jennings's book, it is necessary to know at least some facts about Daisy Ashford, the time she lived in, her social status and her novella The Young Visitors. The title of the book itself, it should be noted, is an indexical of an aspiring aristocrat.

The names of Peter Townsend who "has become Mr. Season for years” (p. 118) [6] and Anthony Powell, Evelyn
Waugh's frequent guest, and Henry Greene (p. 168) [6] represent an upper class society with its parties, and dances at houses in Mayfair and Belgravia, districts in West End London famous for their most expensive properties. Their often recurring and re-recurring names immediately link to social identity.

Allusions to the books and authors can be regarded as the core of upper class social culture, they reflect lifestyle, centuries old traditions, verbal and non-verbal norms cultivated historically, associations with the characters, authors, their mentality and sensibility and constitute a literary code which is part of the cultural code shared by a closely-knit network.

\section{Class 3}

Class 3 includes words implicitly attributing social status by describing his/her appearance - the style of dress or the quality of fabrics of which clothes are made, thus communicating the history of traditions, fashions, styles and cultural codes imparted by the upper classes for centuries. This class of words also falls into the subclass (b) implicatures and presumptions regarding one's own or others' identity position in Mary Bucholtz and Kira Hall's framework and requires background knowledge of the reader to make connections with the upper classes and their non-verbal culture.

Tweed, a rough-surfaced woolen cloth, originally produced in Scotland, is a mark of quality and class: tweeds and ties and headscarves (“...they wore tweeds and ties and headscarves: the sort of clothes I'd only seen in period TV dramas" (p. 5) [6]); a tailcoat and a black top ("He had the sort of tailcoat that looked too old to be hired, and a black top hat which he wore with a degree of frank, baronial confidence...” (p. 25) [6]); teddy-boy drapes, style of dress based on Edwardian fashion, Edward VII's reign; corduroy trousers ("Those people: red-faced men with wrecked teeth and yellow corduroy trousers; middle-aged women in navy blazers and Alice bands, faces like well-bred dogs” (p. 98) [6]); hand-tailored suits (“...they wear manifestly handtailored suits, never quite fashionable, never quite unfashionable, emphasizing the traditional British pear shape of the well-bred male.” (p. 45) [6]); Tony Bennettstyle dinner jacket (“.... rather nice Tony Bennett-style dinner jacket” (p. 112) [6]).

The fabrics of which different items of cloths are made, and some items of dress like a tailcoat, a black top, a dinner jacket, etc. in the course of time got tied up with the image of an upper class person, an aristocrat who could afford the best quality material and thus distinguish themselves. This link between the linguistic forms and social meaning became so stable that the words denoting fabrics and particular items of dress can stand for social identity, they can often be used metonymically.

The illustrative examples in English Oxford Living Dictionary support social implications of the words, as they are part and parcel of formal ceremonies and parties most often held by the upper classes of society. Here are some examples from Oxford Living Dictionary:

1. Prince Alvin was wearing a brilliant black, velvet tailcoat and black britches that looked stunning with his golden crown.' 
2. Swirling dresses, and powered wigs adorned the ladies, and the men wore tailcoats of beautiful silk.'

3.Wednesday, the ambassador's wife, formally dressed in top hat and tailcoat, was scheduled to ride a stallion named High Voltage in an international horse show' [11].

The examples from the dictionary only prove the stable character of social implications of the words denoting some items of clothing (tweeds and ties and headscarves, tailcoats, a black top) and the fabrics of which they are made (corduroy, tweed, silk). It is worth mentioning that these words are often accompanied by adjectives which help to read social identity of the characters - 'and a black top hat which he wore with a degree of frank, baronial confidence...'; 'style of dress based on Edwardian fashion, Edward VII's reign'; 'middle-aged women in navy blazers and Alice bands, faces like well-bred dogs'; 'they wear manifestly hand-tailored suits, never quite fashionable, never quite unfashionable, emphasizing the traditional British pear shape of the well-bred male', etc.

The study of the English literature of different epochs testifies to the enduring character of their social implications: recurring in different contexts and interactional situations over more than two hundreds years the above-mentioned words immediately link with the image of an upper-class person dressed in quite oldfashioned clothes of good quality. The words first evoke a good quality of natural fabrics, high prices of clothes, often hand-tailored and individually made, their style, and, further, lead us to the upper classes of society, which have always tried to elaborate their own socio-cultural code, in dress among other things. They are part and parcel of the upper class register with linguistic and non-linguistic forms constituting it. According to the narrator's observation, women's style and fashion in dress is more diverse than that of men: '...there was uniformity in diversity. Any female, wherever she came from, could be wearing anything' (p. 29) [6].

\section{Class 4}

This group of words signifies social events, which are central for the upper classes to establish rapport with one another and share socio-cultural code of a closed society. Social life becomes a priority in the boarding schools. "What the Harrovians did have in common with the Etonians were the trademarks of the voice, the confidence and they couldn't -give-a-f...- approach to things which I had been brought up to believe were matters of life and death (A-levels, university entrance, keeping your schoolbooks in order). And the only thing any of them worked at all hard at was their social life” (p. 75) [6].

The meaning of the word 'the season', central to the upper class lifestyle, in The Oxford Dictionary is defined as 'a time of year traditionally adopted by the English upper classes for a series of fashionable social events' [11]. In Charles Jennings's book 'the season' is defined as '... anything that posh people might want to do. It is Ascot (the finest horse race in the world), Henley (the Royal Regatta), Queen Charlotte's Ball (on the 25 September at the Grosvenor house in Park Lane), polo at Cowdray Park, The Glorious Twelfth (a term used to refer to 12 August, the start of the shooting season in Great Britain and Northern
Ireland), the Mirabelle Luncheon '(hosted by the undead herself, Baroness Thatcher)', the House of Lords versus House of Commons Speedo Swim (charity swim) and the Brittany Ferries Windsor Horse Trials” (p. 21) [6].

High life revolves round events 'involving horses, water, antiques, the occasional ball' (p. 21) [6], '... which smart people need to do with each other in order to remain socially alive' (p. 37) [6].

In order to attend the events, it is necessary to be eligible for it. Belongingness to clubs determines social identity.

According to Social Identity Theory, a sociopsychological point of view, revolutionary in the 80s, among five most important positions are: identity is a matter of self-concept; the fact of membership is an essential factor; an individual's knowledge of the membership and the value they attach to it are what really count; the emotional side they attribute to it is significant (p. 13) [2], [12]-[13]. Later Mary Buholtz and Kira Hall developed this theory into their framework for the analysis of identity. In the book by Charles Jennings we find that these positions are relevant, club membership is what knits in-group and excludes "others”, out-groups.

Among a few clubs mentioned by the narrator are the Piers Gavestone Club, a dining club only for men, founded in 1977 at the University of Oxford in honour of Piers Gaveston, favourite of King Edward II of England; the Bullingdon Club, also an exclusive male dining club in Oxford for wealthy members, notoriously famous for their destructive behavior; and The Leander Club, one of the oldest rowing clubs in the world, founded in 1818 in Remenham, Berkshire. All the names of the clubs contain a bunch of socio-historical and cultural information and associations; the names have acquired social and cultural implications and turned into social symbols of status. Clubs create in-groups and out-groups and draw a demarcation line between them.

Quintessentially aristocratic are sports: polo - "If ever sport demanded the label posh, polo is that sport” (p. 101) [6]. "Cowdray Park is a big-time in polo terms, not because it's physically very impressive, but because it occupies such a prominent space in the consciousness of horse-minded posh people” (p. 99) [6]. Cricket matches - "And does this make the Eton versus Harrow cricket match, with its mixture of hothouse glory and shame, of society, pleasure and latent humiliation, a metaphor for the whole boardingschool experience? (p. 76) [6]. Sports can be regarded as expression of tough boarding school upbringing; these nonverbal meanings cling to the words and are imparted in speech.

Horses and dogs are also social symbols of upper class culture, and their breeding is of significance. - "Horses are... - objective correlatives for the condition of poshness (p. 97) [6].

Horses as well as dogs “... should have breeding; (they) should have character” (p. 97) [6]. This is the reason why "they're also central to posh culture" (p. 97) [6].

Speaking about sports and hobbies of the upper classes, it should be pointed out that all of them are socially marked. Not only a sport itself (or hunting, or shooting, etc.) but also the whole sphere involved in this sport (or any other pastime) with its terminology and the place (Cowdray Park, 
etc.) acquire social meaning and significance. Each could be regarded separately and become the subject matter for a separate research paper.

All the names of events or clubs mentioned in the book but not fully covered in this article immediately refer to the upper classes of Great Britain as historically they have acquired additional, implicitly expressed social connotations.

\section{E. Class 5}

The voice and a manner of speaking are the most difficult to assimilate and that's why they easily betray the status of a speaker lower on the hierarchy [14]. As the narrator of the book says, '...the voice became my touchstone. The voice is incontestable: the one class identifier, which can't be traded, sold or borrowed.' (p. 35) [6]. 'The voice was a voice I could imitate but never get right' (p. 35) [6]. 'The voice is the difference between officers and ranks, between waiters and waited upon, between judge and accused, between superior and inferior' (p. 35) [6].

In Mary Bucholtz and Kira Hall's framework the voice and a manner of speaking fall under two subcategories, that show (c) displayed evaluative and epistemic orientations to ongoing talk, as well as interactional footings and particular roles; and (d) the use of linguistic structures and systems that are ideologically associated with specific personas and groups (p. 21) [1].

The upper class manner of speaking mirrors their behavioral, evaluative and epistemic stance on life and people, and their leading position in society, and it is socially marked [15], [16].

The highlighted voice parameters found in the descriptions of the book are the following: 'a monotonous drone of their voices' (p. 19) [6]; 'the voice - drifting over the grasp' (p. 36) [6]; 'He had precisely the sort of voice and bearing, of course, which spoke of nothing but privilege and fifty-pound notes: patrician baritone, clear but restrained smile on the face, waves of oiled, grey hair swept back to the nape of the neck, a minute, angular quarter-bow from the waist as he leaned forward to patronize the race form-seller' (pp. 24-25) [6]; 'He sounded as if he were talking to his stockbroker rather than a grimly amenable form-card saleswoman in overalls' (p. 25) [6]; 'the drawling top-hatters' (p. 41) [6]; 'a tone of friendly condescension, or as a father would talk to his earnest but none-too-bright son' (p. 40) [6]; ' At Ascot, the posh-sounding men not only had mellifluous voices. They also generally had something wrong with their faces...' (p. 45) [6]; ' The posh-sounding women were generally a lot less ghastly to look at, but tended to have visibly paralysed upper lips, numb with permanent, unhappy smiles. Which must have helped with the accent' (p. 45) [6]; '...the low, continuous roar of wellbred voices like waves on a shingle beach. There is a sense of wealth and privilege in the air' (p. 178) [6]; 'posh sounding men and women' (p.45) [6], 'a cultured voice' (p. 85) [6], 'Eton voices' (p. 63) [6]; 'You get your grounding your voice - at prep school, and then you have the rest of your sensibilities radically altered at your great, boarding, public school.' (p. 65) [6], '...pouting and drawling and telling them that yah...' (p. 8) [6] etc.

In the adduced examples voice parameters marked as low, patrician, mellifluous, soft, well bred, condescending, posh serve as indices of identity and are recognized as such. The voice characterized by any of the above-mentioned adjectives comes to index distance, condescension and superiority in interaction and gets linked to the upper classes of society. These are stable, centuries old semiotic signs of upper class culture that in conjunction with other indices of verbal and non-verbal character form the semiosphere of upper class culture.

At Ascot, according to the narrator's observation, the manner of speaking and the voice can be the only real marker of social identity. The following episode is noteworthy as it helps to see social identifiers:

(About Ascot) 'I made two discoveries. Not only were there the authentic vocalized sounds of the well-bred, but the sole topic of conversation was establishing how you were and with whom, and where you were going to be in the immediate future - the only topic, it seemed, for smart people to use by way of small talk. One exchange, between two middle-aged patricians in black toppers, went precisely like this:

'Hello!'

'Hello!'

'Hello!'

'How are you?'

'Terribly well! Super to see you!'

'Where's your lady wife?'

'Arabella?'

'Arabella.'

'Arabella. She’s over there, she’s right up there.'

'Oh, right, she's over there.'

The chap married to Arabella pointed in the direction of the Tote board.

'Yes, she's over there, right now. I'm going over there in a minute.' (p. 27) [6].

The narrator of the book remarks that at social gatherings like Ascot the conversation may go on for hours 'without letting it get fixated on a point' (p. 33) [6]. 'These conversations were complete. The whole point seemed to be to keep the exchange ticking over without committing oneself to anything so rash as an idea' (p. 31) [6]. '...the posh people, the smart set, said nothing at all, in a constant, gentle swell of verbiage' (p. 31) [6]. And that is what serves as a class marker differentiating the socially smart from the 'merely well turned-out', it is 'the sort of trademarks that, as Nancy Mitford observed, allow one 'U-speaker [to] recognize another U-speaker almost as soon as he opens his mouth' (p. 34) [6]. Another visual mark of social identity is “...visibly paralysed upper lips, numb with permanent, unhappy smiles. Which must have helped with the accent” (p. 45) [6].

Of interest is the narrator's observation that states that the upper classes almost never 'put an accent not their own' (p. 48) [6], and in order to assimilate their voice, it is necessary, first, to study in a preparatory school and, then, in a good public school, which proves that social and cultural code is inculcated in childhood.

Socially privileged classes of Great Britain have a distinctive pronunciation - 'a hyper-correct version of Received Pronunciation’ (p. 19) [6], posh English, incomplete sentences ('Super! Super! Must press on! Got to 
lose some money!'); vocables ('hice' for house, 'strawdinreh’ for extraordinary, ‘Quinmahthah’ for Queen Mother); emphases on adverbs or adjective ('That is SUCH fun! Are you REALLY going to do it? You're SO lucky! Isn’t she looking MARVELOUS?') (pp. 34-35) [6]. Marked pronunciation is often used to index social identity of characters in fiction and is part of the linguistic arsenal of the upper class register.

The voice parameters and a manner of speaking are closely connected with a manner of behavior.

The narrator of the book is always bewildered by the way the elite schools' students behave, respond and prepare for exams. 'Westminster boys, in particular, used to send me dizzy with apprehension and self-consciousness (p. 5) [6]; 'Westminster turned out a race of gangling, intimidating, hyper-cultured, real tennis-playing giants with basso voices - voices that sounded the way a good piece of furniture would sound if it could speak (p. 5) [6].

The preparation for exams is described in the following way: '...He went on the most extravagant holidays, never did a stroke of work (after one particular sybaritic term, he was seen preparing for his end-of-term history exams with a copy of The Ladybird Book of the Normans) and drank gin and tonics and in an unfathomably relaxed and adult fashion.' (pp. 5-6) [6]. Or: 'This second Harrovian, far from being a paragon of suavity, was such a fabulous moral degenerate that could never visit another person's room without damaging it in some way, sometimes even destroying it completely.' (p. 6) [6].

Pretentiousness which marks the closed boarding schools' boys was assimilated by the narrator after a year at Oxford, which finds its reflection in the following episode: 'When my parents dished the Sunday lunch, I would say, 'Where is the silverware? Can we not dine by candlelight, in a more gracious manner? What kind of wine do you call this? I learned to say yah instead of yeah at Oxford' (p. 8) [6].

Indicative of social identity is the behavior of a

Sloane in the following episode worth adducing: 'I was walking down a road in Battersea one night. A Sloane boy brought me up short and said in the standard Sloane accent, clipped and drawling at the same time, 'Do you know the way to Warriner Gardens?' I replied with my usual repertoire of shrugs and grimaces and nice-guy-but-useless gestures and said no, I didn't. He took a step and shouted at me, 'THEN FUCKING WELL LEARN!' And sauntered off into the darkness. I was so affronted, so startled, I just stood there about a minute with my mouth open (p. 9) [6].

Similar episodes are found in James Lees-Milne's diaries with Lady Bridget and Randolph Churchill - 'Randolph Churchill appears, manifestly described as an 'aristocrat' because he 'did not care a damn for everybody; was possessed of unbounded confidence which amounted to insolence' (p. 18) [6]. Or ... 'the sort who bounce out of taxi with a cry of 'Bye, darling,' and then tread on my feet the sort, in other words, who remind me on a daily basis that I am a lesser person than they are and that, taken as a whole, our society is based on a system of priorities which clearly made some kind of sense around the time of the Indian Mutiny, but is now a kind of madness, a desperate conservatism taken to insane lengths.' (p. 20) [6].
These extracts from the book suffice to show socially marked epistemic and evaluative milestones of the upper class culture. They reflect various aspects of life and add to our understanding how words reflect culture and construct identity.

\section{CONCLUSION}

Thus, the analysis of the novel People Like Us, A Season Among The Upper Classes by Charles Jennings has showed that words not only denote objects and phenomena of real life, but they acquire additional meanings and connotations of a different order. Reflecting lifestyle, traditions, and mentality of a community or a layer of society, they attain meanings of historical, cultural, social and ideological orders which turn words into markers or indices of identity. In the book on "the surface level" the upper classes of Great Britain are represented by words, which directly indicate their social status (an earl, a viscount, peers, a baron, the upper crust etc.) or by naming socially marked institutions, events and upper class representatives. As for the latter, they can also be identified either non-verbally, visually, by their look and clothes they wear, by quality of clothes and the material and fabrics they are made of, or by ear, their pronunciation, voice, manner of speaking and conversation. Although allusions do not belong to easily understood sources of information "on the surface level" and require deep knowledge of the readers to be able to grasp all the associations and additional meanings they convey in speech, in the book under analysis we find allusions to authors representing the classes or the books and reference books which are instructions, guidelines and recommendations for those who aspire to become one of "them". When we speak about 'the surface level' we mean linguistic means translating social identity of the speaker without difficulty and juxtaposed to the linguistic means used by the upper classes on "an in-depth level" - requiring an effort on the part of a listener or speaker to notice and grasp them - the categories of words they use, the peculiarities of using modal verbs, understatement-overstatement, adjectives and so on. This level of reading the meanings attached to the alluded words requires special studies to examine how educational, social, professional, etc. statuses of the speakers find their reflection in a complex of linguistic means; and this aspect of linguistic social identity has already been highlighted in the articles.

\section{REFERENCES}

[1] M. Bucholtz and K. Hall, "Locating identity in language," in Language and Identity, C. Llamas and D. Watt, Eds. Edinburgh University Press, ch. 2, pp. 18-27, 2010.

[2] J. E. Joseph, "Identity,” Language and Identity, C. Llamas, D. Watt Ed. Edinburgh University Press, ch. 1, pp. 9-18, 2010.

[3] J. Blommaert, "Sociolinguistics and discourse analysis: Orders of indexicality and polycentricity,” Journal of Multicultural Discourses, ch. 2, pp. 115-130, 2007.

[4] M. Silverstein, "Indexical order and the dialectics of sociolinguistic life,” Language and Communication, vol. 23, pp. 193-229, 2003.

[5] J. L Dessalles, Why We Talk: The Evolutionary Origins of Language, trans. James Grieve, Oxford: Oxford University Press, 2007, p. 363.

[6] C. Jennings, People Like Us. A Season Among Upper Classes, Abacus, p. 218, 1998.

[7] P. Bourdieu, "Language and symbolic power: The economy of linguistic exchanges,” G. Raymond and M. Adamson, Eds. John B. Thompson, Cambridge: Polity Press, 1991. 
[8] R. Wodak, Language, Power and Ideology, Amsterdam: John Benjamins, 1989.

[9] A. Agha, Language and Social Relations, New York: Cambridge University press, 2007.

[10] M. Silverstein, "Metapragmatic discourse and metapragmatic function," in Reflexive Language, J. Lucy, Ed. Cambridge: Cambridge University Press, 1993, pp. 33-58.

[11] English Oxford living dictionary. [Online]. Available: https://en.oxforddictionaries.com

[12] H. Taifel, "Social categorization, social identity and social comparison" in Differentiation between Social Groups: Studies in the Social Psychology of Intergroup Relations, H. Taifel, Ed. London: Academic Press, 1978, pp. 61-76.

[13] J. Turner, M. Hogg, P. Oakes, S. Reicher and M. Wetherell, Rediscovering the Social Group: A Self-Categorization Theory, Oxford: Blackwell, 1987.

[14] A. Agha, "Voice, footing, enregisterment," Journal of Linguistic Anthropology, vol. 15, no. 1, pp. 38-59, 2005.

[15] N. Coupland, Style, Variation and Identity, Cambridge: Cambridge University Press, 2007.

[16] J. Edwards, Language, Society and Identity, Oxford: Blackwell, 1985.

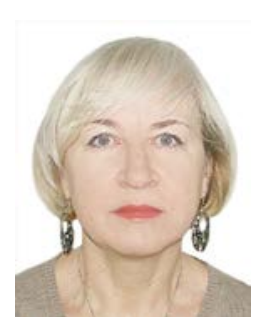

Tatiana A. Ivushkina is a professor at MGIMO (University) in Moscow, Professor at English Department №3, Moscow, Russia. She is a doctor of philology, an advanced $\mathrm{PhD}$ from Lomonosov Moscow State University for the thesis on Sociolinguistic aspects of English speech development (in speech portrayals of the upper classes of Great Britain in the 19-20th century English literature) in 1998.

Her research interests include social linguistics, stylistics, stylization in speech portrayals, upper-class speech, English \& American literature and culture, innovative methods of teaching and intercultural communication.

She published 73 articles, 4 monographs and 4 manuals (in coauthorship included). 